\title{
Anti-HDV seroprevalance among patients with previous HBV infection
}

\author{
Abdurrahman Sahin, ${ }^{1}$ Suzan Gurocak, ${ }^{1}$ Nurettin Tunc, ${ }^{1}$ Ulvi Demirel, ${ }^{1}$ Orhan Kursat Poyrazoglu, ${ }^{1}$ \\ Handan Akbulut, ${ }^{2}$ Mehmet Yalniz, ${ }^{1}$ Zulal Asci Toraman, ${ }^{2}$ Ibrahim Halil Bahcecioglu ${ }^{1}$ \\ ${ }^{1}$ Department of Internal Medicine, Faculty of Medicine, Firat University, Division of Gastroenterology, Elazig, Turkey \\ ${ }^{2}$ Department of Microbiology, Faculty of Medicine, Firat University, Elazig, Turkey
}

\begin{abstract}
OBJECTIVE: This prospective study aimed to determine the prevalence of anti-HDV seropositivity among subjects who had previous hepatitis B virus (HBV) infection.

METHODS: Subjects who were admitted to the gastroenterology inpatient clinic of our hospital between August 2016 and July 2017 were screened for previous HBV infection. The subjects who had HBV serology compatible with resolved HBV infection were recruited in the study, and the seroprevalance of anti-HDV was studied. Participants answered a short questionnaire regarding their family history of chronic hepatitis $B(\mathrm{CHB})$ and chronic hepatitis $\mathrm{D}(\mathrm{CHD})$ infection and risk factors for transmission. Subjects who were anti-HDV positive were recalled for a control visit, and HBV-DNA and HDV-RNA were assayed in the blood samples of the responders.
\end{abstract}

RESULTS: Among 554 subjects who had previous HBV infection, 53 (9.6\%) were anti-HDV positive. The mean age was $63.1 \pm 15.4$ years in the anti-HDV-positive group and $65.9 \pm 15.6$ years in the anti-HDV-negative group $(p=0.19)$. The most common risk factor for both groups was dental procedures ( $89 \%$ vs $80 \%, \mathrm{p}=0.33$ ). Anti-Hbc IgG, anti-Hbs, and anti-HBeAg seropositivity did not differ between the anti-HDV-positive and -negative groups (for all, $\mathrm{p}>0.05$ ). Although HDV-RNA was not detectable in all studied samples, only one subject had detectable HBV-DNA in the anti-HDV-positive group.

CONCLUSION: This study highlighted the prevalence of anti-HDV among subjects who had resolved HBV infection. Longterm follow-up studies, including after the resolution of both infections, are needed to explore HBV-HDV interactions and the behavioral patterns of these viruses.

Keywords: Anti-HDV, HBV-DNA, HDV-RNA, previous HBV, transmission route.

Cite this article as: Sahin A., Gurocak S., Tunc N., Demirel U., Poyrazoglu O. K., Akbulut H., Yalniz M., Asci Toraman Z., Bahcecioglu I. H. Anti-HDV Seroprevalance among Patients with Previous HBV Infection. North Clin Istanb 2018;5(2):132-138.

Lepatitis delta virus (HDV) is a single-stranded 1 circular RNA satellite virus and is the smallest of the known mammalian viruses [1,2]. HDV requires the hepatitis $B$ virus (HBV) envelope proteins for the dissemination of virus particles [3]. Thus, hepatitis delta infection occurs only in hepatitis B surface antigen ( $\mathrm{HBs} \mathrm{Ag}$ )-positive individuals.

Chronic hepatitis D (CHD) is the most severe form of viral hepatitis, with the clinical features of accelerated progression to cirrhosis, increased risk of hepatocellular carcinoma, and early decompensation in patients with cirrhosis. CHD affects approximately 15-20 million patients among the approximately 400 million people chronically infected with HBV worldwide. HDV is found throughout the world, but its prevalence, incidence, clinical features, and epidemiological characteris-

Received: January 23, 2018 Accepted: April 13, 2018 Online: May 21, 2018

Correspondence: Dr. Abdurrahman SAHIN. Department of Internal Medicine, Faculty of Medicine, Firat University, Division of Gastroenterology, Elazig, Turkey

Phone: +90424233 3555 e-mail: arahmansmd@yahoo.com

(c) Copyright 2018 by Istanbul Provincial Directorate of Health - Available online at www.northclinist.com 
tics vary according to the geography [4]. Turkey is one of the high prevalence countries, and there are geographical differences between the western and eastern regions of Turkey. Epidemiological studies from the eastern and southeastern Anatolia regions have reported a prevalence of $16 \%-33 \%$ for delta hepatitis superinfection among chronic hepatitis B (CHB) patients [5-7]. Similarly, lower rates of $\mathrm{CHD}$ ( $2 \%$ to $7 \%$ ) were reported in the western regions of Turkey $[7,8]$. Studies evaluating antibodies to HDV (anti-HDV seropositivity) among $\mathrm{HBsAg}$ positive subjects from Turkey, Italy, and Germany found a prevalence of $8 \%-12 \%$ [9-11].

Resolved or previous HBV infection is defined as the clearance of $\mathrm{HBsAg}$, with or without the development of antibodies to HBsAg (anti-HBs) and with or without antibodies to hepatitis B core antigen (anti-HBc). Resolution of the infection occurs spontaneously in inactive HBV carriers, at an annual rate of $0.5 \%-2.3 \%$ for treated $\mathrm{CHB}$ patients [12-15]. The loss of $\mathrm{HBsAg}$ is the primary end point of $\mathrm{CHB}$ treatment according to the international guidelines $[16,17]$. The loss of HBsAg is also the ultimate goal in CHD treatment.

The seroprevalence of anti-HDV has been studied in different populations including inactive $\mathrm{HBV}$ carriers and patients with $\mathrm{CHB}$ and cirrhosis $[5-7,9,10]$. No reports on the HDV prevalence among those who have resolved HBV infection have been published to date in the peer-reviewed literature. The current study aimed to determine the anti-HDV prevalence among subjects with resolved HBV infection in an area that is highly endemic for HDV.

\section{MATERIALS AND METHODS}

\section{Subjects and Study Design}

The current study was conducted on 2736 subjects (1396 females and 1340 males) who were admitted to the gastroenterology inpatient clinic of our hospital between August 2016 and July 2017 because of several complaints and underwent $\mathrm{HBV}$ and hepatitis $\mathrm{C}$ virus (HCV) serologic testing for the assessment of previous $\mathrm{HBV}$ infection. If the HBV serology was compatible with one of the following three scenarios and the HCV serology was negative, the patient was considered to have previous HBV infection and was recruited in the present study: [1] HBsAg-negative, anti-HBs antibody (ab)-positive and anti-hepatitis $\mathrm{B}$ core (anti-HBc) IgG ab-positive; [2] $\mathrm{HBsAg}$-negative, anti-HBs ab-negative and anti-HBc
IgG ab-positive; and [3] HBsAg-negative, anti-HBs abpositive and anti-HBc IgG ab-negative (patients in the last group were questioned to determine whether they had been vaccinated against $\mathrm{HBV}$ or refused the HBV vaccination). Previous $\mathrm{HBV}$ infection was detected in 554 subjects (268 females and 286 males); these subjects were asked about their family history of $\mathrm{CHB}$ and $\mathrm{CHD}$ and risk factors for transmission [such as prior surgery, dental procedures, blood transfusion history, intravenous (IV) drug use, high-risk sexual behaviors, tattoos, and piercings]. Complete blood count; liver function tests including alanine aminotransferase (ALT), aspartate aminotransferase (AST), albumin, and bilirubin levels; international normalized ratio (INR); and anti-HDV were assessed. The presence and absence of anti-HDV are shown in Figure 1. Subjects positive for anti-HDV were recalled for a control visit, and HBV-DNA and HDV-RNA were studied in the blood samples of the responders (39 anti-HDV-positive subjects). Subjects who had liver cirrhosis, seroclearance of HBsAg after the treatment of $\mathrm{CHB}$ and/or $\mathrm{CHD}$, previous or concurrent exposure to $\mathrm{HCV}$, those taking immunosuppressive medications, and those with disorders causing immune system dysfunction such as hematological diseases, chronic renal failure, or rheumatologic diseases were excluded. Age $<18$ years and pregnancy were other exclusion criteria. The current study was approved by the institutional review board. Informed consent was obtained from all individual participants included in the study.

\section{HBV and HDV Serology}

All blood samples were analyzed in the central clinical microbiology laboratory at our hospital. Approximately $5 \mathrm{~mL}$ of venous blood was collected from 2736 subjects and then centrifuged at $4000 \mathrm{rpm}$ for $5 \mathrm{~min}$ for the serologic testing of HBV and HCV. Serum samples were obtained and studied on the same day. Anti-HDV was also studied using the same method in the 554 subjects who had previous HBV infection. The 53 subjects who had anti-HDV seropositivity were recalled. The blood samples of the 39 responder subjects who were antiHDV positive were collected into tubes with EDTA and centrifuged at $4500 \mathrm{rpm}$. Plasma samples were separated and stored at $-20^{\circ} \mathrm{C}$ until the study date. Plasma samples were kept at room temperature and dissolved before the beginning the study for HBV-DNA and HDV-RNA and then tested without delay.

Serum samples were tested for $\mathrm{HBsAg}$, hepatitis B 
e-antigen ( $\mathrm{HBeAg}$ ), anti-HBs, anti-HBc IgG, antibody against $\mathrm{HBeAg}$ (anti-HBeAg), and anti-HCV with macro enzyme-linked immunosorbent assay (ELISA) using Abbott Architect kits in the Abbott Architect i2000 SR system (Abbott, Axsym, Ireland) according to the manufacturer's instructions. The presence of anti-HDV was analyzed using micro-ELISA (HDV Ab, Enzyme Immunoassay Test Kit, Delta Biologicals, Italy) with the Triturus system (Triturus, Grifols, Spain) according to the manufacturer's instructions. This assay has been reported to have a sensitivity over $98 \%$ and a specificity over $98 \%$. The values over 1.1 were accepted as positive for anti-HDV. Isolation of HBV-DNA and HDV-RNA in the blood samples was performed with QIAsymphony ${ }^{\oplus}$ DSP Virus/Pathogen Midi Kit, Version 1 extraction kits (QIAGEN, Germany). The presence of HBV-DNA and HDV-RNA was assessed by the real-time polymerase chain reaction (PCR) method using Rotor Gene Q (QIAGEN, Germany). HBV-DNA was tested using Artus ${ }^{\circledast}$ HBVQS-RGQ kit- 24, V1 kits (IQAGEN, Germany); HDV-RNA was also tested using Fluorion HDV Real-Time PCR kit-HDV QNP1.0 (IONTEK, Turkey) according to the manufacturer's instructions.

\section{Statistical analysis}

Statistical analyses were performed using SPSS (version 21; SPSS Inc., Chicago, Illinois, USA). Categorical variables are presented as frequencies and percentages. Variables with a normal distribution are represented as mean $\pm \mathrm{SD}$, those with a non-normal distribution and ordinal variables are described as median (interquartile range). Categorical variables were compared using the $x^{2}$ test or Fischer's exact test. Differences between continuous variables were analyzed using Student's t-test and Mann-Whitney $\mathrm{U}$ test in a proper approach. $\mathrm{P}<0.05$ was considered statistically significant.

\section{RESULTS}

Overall, 554 subjects with a mean age of $65.7 \pm 15.5$ years were screened for the presence of anti-HDV. Of these subjects, 268 (48\%) were women and 286 (52\%) were men. Among the participants, anti-HDV positivity was found in 53 subjects (9.6\%) (Fig. 1). The demographic, clinical features, and laboratory findings of the anti-HDV-positive and-negative groups are shown in Table 1 . While 11 subjects $(20.8 \%)$ had a family history

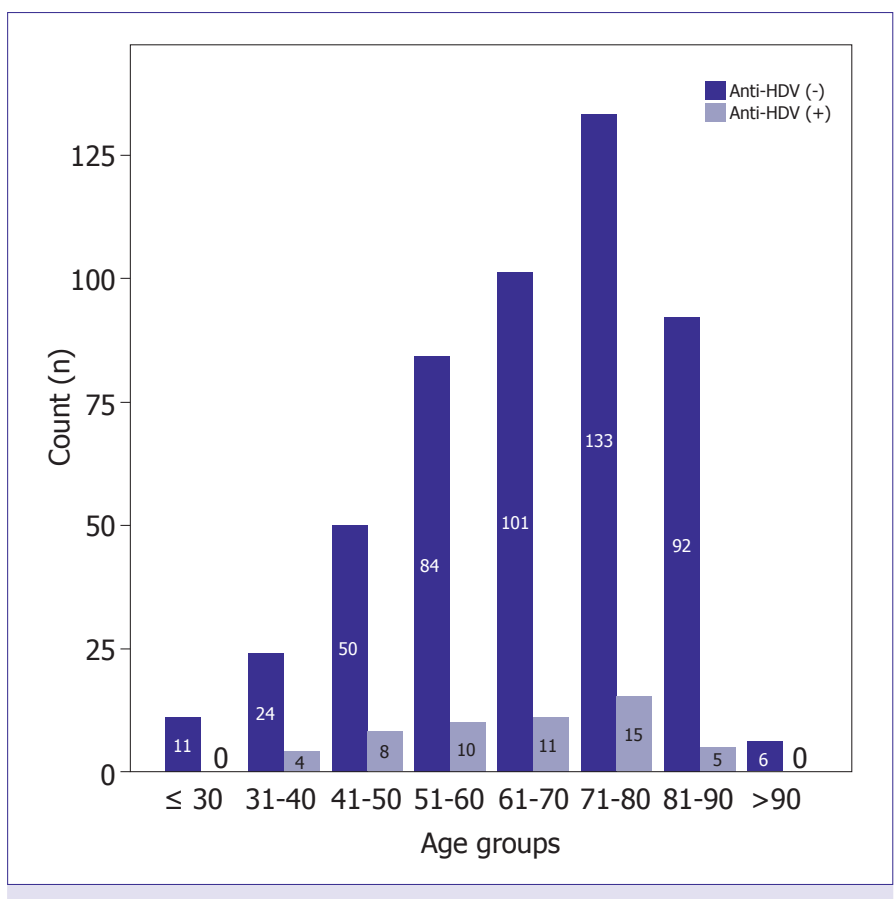

FIGURE 1. Distribution of the subjects according to the presence or absence of anti-HDV by age.

of $\mathrm{CHB}$ and one $(1.9 \%)$ had a family history of CHD in the anti-HDV-positive group, the ratios of $\mathrm{CHB}$ and CHD family histories in the anti-HDV-negative group were $17 \%$ and $2.6 \%$, respectively (for all, $p>0.05$ ). Laboratory parameters did not differ between the anti-HDVpositive and-negative subjects (for all, $\mathrm{p}>0.05$ ).

Serological analysis of participants is shown in Table 2. The presence of anti-HBs, anti-HBc IgG, and anti$\mathrm{HBeAg}$ was not different between the anti-HDV-positive group and -negative group. The participants were neither HbeAg-positive nor anti-HBc IgM-positive. Although HDV-RNA was undetectable, HBV-DNA was detectable in only one subject (2.6\%) among the 39 responders in the anti-HDV-positive group.

\section{DISCUSSION}

In the present study, the anti-HDV seropositivity was 9.6\% among subjects who had previous HBV infection. To our knowledge, this is the first study to investigate $\mathrm{HDV}$ infection among subjects who had previous HBV infection.

Although anti-HDV seroprevalence has been commonly studied in different HBV patient groups, there is little information on the exposure of patients with resolved HBV to HDV. Approximately 25 years ago, anti-HDV 
TABLE 1. Clinical, demographic features, and laboratory data of the participants

Patient count, $\mathrm{n}(\%)$
Age, years mean $\pm \mathrm{SD}$
Sex, Female $\mathrm{n}(\%)$
Risk factors and transmission route, $\mathrm{n}(\%)$
HBV family history
HDV family history
Surgery
Dental procedure
Blood transfusion
IV drug use
Sexual partner with HBV
Tatoo or piercing
Laboratory findings
White blood count
Hemoglobin
Hematocrit
Platelet, x103
ALT
AST
Albumin
Bilirubin
INR

Anti-HDV negative

$501(90,4)$
$65.9 \pm 15.6$
$248(49)$
$85(17)$
$13(2.6)$
$334(67)$
$403(80)$
$148(30)$
$3(0.6)$
$20(4.0)$
0
$6945 \pm 1800$
$12.9 \pm 1.8$
$39.4 \pm 5.6$
$250(198-311)$
$21(15-31)$
$24(18-31)$
$3.99 \pm 0.48$
$0.6(0.4-0.9)$
$1.06 \pm 0.11$

$\mathrm{p}$

$\begin{array}{cc}53(9.6) & \\ 63.0 \pm 14.4 & 0.19 \\ 24(45) & 0.64 \\ 11(21) & 0.49 \\ 1(1.9) & 1.00 \\ 35(66) & 0.92 \\ 47(89) & 0.33 \\ 15(28) & 0.85 \\ 0 & 1.00 \\ 3(5.7) & 0.48 \\ 0 & \\ 7170 \pm 2300 & \\ 12.4 \pm 1.8 & 0.39 \\ 37.9 \pm 4.8 & 0.92 \\ 237(198-310) & 0.87 \\ 22(15-36) & 0.65 \\ 26(20-31) & 0.67 \\ 4.02 \pm 0.52 & 0.17 \\ 0.7(0.6-0.9) & 0.54 \\ 1.09 \pm 0.15 & 0.46 \\ & 0.11 \\ & \\ & \end{array}$

TABLE 2. Serological analysis of the participants

\begin{tabular}{lccc} 
& Anti-HDV negative $(\mathrm{n}, \%)$ & Anti-HDV positive $(\mathrm{n}, \%)$ & $\mathrm{p}$ \\
\hline Anti-HBs positivity & $420(84)$ & $44(83)$ & 0.88 \\
Anti-HBs titer IU/mL & & & 0.48 \\
$10-99$ & $218(44)$ & $26(49)$ & \\
$100-999$ & $153(30)$ & $12(23)$ & \\
$\geq 1000$ & $49(10)$ & $6(11)$ & 0.22 \\
HBeAg positivity & 0 & $21(40)$ & 0.18 \\
Anti-HBeAg positivity & $157(31)$ & $39(74)$ & 0.37 \\
Anti-HBc IgG positivity & $407(81)$ & $30(57)$ & \\
Anti-HBs+Anti-HBc IgG positivity & $326(65)$ & $14(26)$ & $9(17)$ \\
Isolated Anti-HBs positivity & $94(19)$ & $1(2.6)$ & \\
Isolated Anti-HBc IgG positivity & $81(16)$ & 0 & \\
HBV DNA* (detectable) & NA & NA & \\
HDV RNA* (detectable) & & & \\
\hline
\end{tabular}

* HBV DNA and HDV RNA were studied in 39 subjects who responded to recall. NA: Not available

positivity was first reported in $\mathrm{HBs} \mathrm{Ag}$-negative IV drug users $[18,19]$. Later, a study conducted on Mongolian subjects found anti-HDV positivity among subjects with resolved $\mathrm{HBV}$ infection ( $\mathrm{HBsAg}$-negative and anti-HBc IgG-positive) [20]. In this study on Mongolian subjects, 20 of the 170 subjects $(11.8 \%)$ who had pre- 
vious $\mathrm{HBV}$ infection were anti-HDV-positive and one of them (0.6\%) was also HDV-RNA-positive. A survey in Switzerland also found a $13 \%$ prevalence of $\mathrm{HBsAg}$ negativity and a $10 \%$ prevalence of anti-HBs positivity among subjects who had proof of HDV infection consisting of at least anti-HDV positivity [21]. These studies are evidence of HDV exposure in $\mathrm{HBsAg}$-negative subjects by anti-HDV.

Several hypotheses can be discussed with respect to this issue. First, some cross-sectional studies demonstrated the disappearance of $\mathrm{HBs} \mathrm{Ag}$ in patients with $\mathrm{CHD}$ over time. Niro et al. demonstrated HBsAg loss in six patients (10\%) among 60 patients with CHD (HBs Ag-positive and anti-HDV positive) who were not treated with interferon (IFN) or who were non-responders to IFN after a mean of 4 years of follow-up [22]. Another longterm follow-up study also demonstrated seroclearance of $\mathrm{HBsAg}$ in 22 of 299 patients ( $7 \%$, a rate of 0.25 per year) [23]. Half of these patients were untreated, and seroconversion to anti-HBs developed in all patients. In another study from Spain, HBsAg seroclearance was found to be $7 \%$ among 158 CHD subjects, with a median follow-up of 75 months [24]. The previously mentioned studies reveal that $\mathrm{HBsAg}$ loss and even anti-HBs seroconversion have been seen in the long-term follow-up of patients with CHD. However, participants who had any cause of chronic hepatitis and cirrhosis were excluded in the current study.

HDV is transmitted mainly via the parenteral route. Considering the older age of the study participants (mean age, 65.5 years) and data from earlier studies in Turkey demonstrating an increasing incidence of exposure to HBV with age, unsafe hospital-based medical procedures in earlier time periods and household contacts, these might be the cardinal sources of dual HBV/ HDV infection in this endemic area. HDV was discovered as an epidemic in the 1970s and 1980s [24]. This is related to a cumulative risk of HDV exposure over time. Thus, most of the study participants might have been infected with HDV 2-4 decades ago. As shown Figure 1, it appears that HDV exposure continued for two decades. After the beginning of a universal vaccination program in Turkey in 1999, there was an accelerated reduction in HDV exposure related to HBV exposure.

The clinical scenario of HDV infection is variable, and asymptomatic carriage or benign hepatitis is also described in the endemic areas [1]. Resolution of dual infection occurs in most co-infected cases. Based on the current knowledge, a loss of $\mathrm{HBs} A g$ with the presence of HDV is the characteristic finding of the resolution of $\mathrm{HBV} / \mathrm{HDV}$ coinfection. However, the time required for anti-HDV to disappear is not well known. Acute HBV/ HDV coinfection usually appears first as IgM anti-HDV and then converts to IgG anti-HDV. In superinfection, HDV antibodies appear early as IgM, followed by $\operatorname{IgG}$ anti-HDV [4]. Generally, anti-HDV IgM antibodies become detectable approximately 4 weeks after the infection, but then disappear several weeks after the onset of acute coinfection $[25,26]$. Conversely, IgM anti-HD may persist over time in patients whose infection progresses to chronicity. Anti-HDV IgG antibodies persist for a long time in the course of chronic superinfection [26]. Anti-HDV IgG remains positive for years after the successful treatment of CHD including HBsAg clearance. There are scarce data on the disappearance of anti-HDV IgG antibodies. The loss of anti-HDV was reported in untreated patients and in patients who undergo liver transplantation for CHD after the fifth year of seroclearance of HBsAg or liver transplantation [22, 27]. Thus, some of our subjects might be surviving cases of $\mathrm{HBV} /$ HDV coinfection. Furthermore, the current study is a cross-sectional study on subjects who had resolved HBV infection. Thus, it was not possible to detect the duration of HBsAg seroclearance. The lower seroprevalence of anti-HDV in subjects aged $>50$ years might be because of the accelerated seroclearance of anti-HDV.

The preferred screening method for the diagnosis of HDV infection is the measurement of anti-HDV. The diagnosis of HDV infection is based on the presence of HDV-RNA after the positive test results of anti-HDV. There are several commercial anti-HDV tests using the method of simultaneous competitive assays [28]. In a recent study, it was shown that commercially available assays can effectively detect antibodies to HDV [29]. Most of these tests are qualitative measurement of anti-HDV. Recently, quantitative microarray antibody capture (Q$\mathrm{MAC}$ ) assay was shown closely related with the presence of HDV-RNA (sensitivity, 100\%; specificity, $94.3 \%$ for Q-MAC assay) [30]. Although anti-HDV IgG is the most commonly used tool to screen patients with $\mathrm{CHB}$ for concomitant HDV infection or previous infection, competitive assays measure all types of antibodies to HDV $[1,28]$. In the current study, we used total antiHDV as a screening tool to determine the exposure to HDV. Although we could not test the participants for anti-HDV IgM separately, they were all negative for anti-HBc IgM. Thus, we considered that it was not possible 
to have acute HBV/HDV coinfection in our study population. Several studies have found a higher prevalence of HDV exposure by HDV-RNA compared with antiHDV IgG $[9,31]$. Further, the expense of HDV-RNA measurement compared with anti-HDV measurement restricts the common use of this assay as a screening modality.

Another hypothesis is that occult HBV infection may result in undetectable $\mathrm{HBsAg}$ and undetectable or low levels of HBV-DNA in dual infection, as a consequence of the suppression of HBV by HDV. In the present study, HDV-RNA was negative in all subjects, and only one subject had detectable HBV-DNA. A study by Delfino et al. demonstrated the presence of HDV by HDV-RNA in three cases that had occult HBV infection (HBsAg-negative, anti-HBc IgG-positive, and HBV-DNA-positive in two of them) [32]. Interestingly, all three of these subjects were anti-HDV negative, and the authors concluded that large HD-Ag variants were responsible for covert HDV infection in these subjects. It can be concluded that unidentified occult HDV infection might be a part of the clinical spectrum of HDV. The clinical importance of resolved dual HBV/HDV infection arises in cases of patients taking immunosuppressive agents. Data on this topic is derived from patients undergoing liver transplantation for $\mathrm{CHD}$. Before effective antiviral treatment using nucleoside analogs and hepatitis B immunoglobulin (HBIG), the reinfection rate after liver transplantation had reached up to $77 \%$ and reinfection was similar to the HBV/HDV coinfection pattern [33]. Helper-independent HDV infection was first described in patients undergoing liver transplantation with isolated HDV infection in the liver and HDV viremia $[34,35]$. Although this form of HDV is considered not to have clinical importance and isolated HDV infection may become symptomatic only after HBV reactivation, one recent report from Japan drew attention to this issue [36]. A patient who underwent liver transplantation for CHD-related cirrhosis 4 years prior was being treated with entecavir, HBIG, corticosteroid, and mycophenolate mofetil. After the discontinuation of entecavir treatment, a hepatitic attack with reversion of $\mathrm{HBsAg}$ and $\mathrm{HBeAg}$ occurred. In the retrospective anal$y$ sis of the patient's serum and liver tissue, HDV-RNA was detected. The authors of this report attributed detectable HDV-RNA to the repackaging of HDV after the beginning of HBV replication and they concluded that long-term steroid treatment, which is clearly related with HBV reactivation, may also cause HDV reactiva- tion. As a result, HDV reactivation after HBV reactivation should be kept in mind in patients who have resolved HBV infection and are given immunosuppressive treatments, particularly corticosteroids. These subjects should also be checked for HDV exposure in the endemic areas.

There are some limitations to the current study. First, we screened a study population for HDV exposure by antiHDV. The replication of HDV has been detected most efficiently using HDV-RNA measurement. Testing the entire study population for HDV-RNA would have been a more accurate approach for investigating HDV replication. Second, some of the anti-HDV-positive subjects did not respond to the request for HDV-RNA and HBV-DNA measurements. Another limitation is that our results cannot be generalized to the Turkish population because of epidemiological differences in the Eastern and Western parts of Turkey in terms of HDV prevalence. Finally, the current study is a cross-sectional study investigating anti-HDV seroprevalence in subjects with previous $\mathrm{HBV}$ infection. Additionally, long-term follow-up studies are needed to determine the clinical importance of anti-HDV seropositivity.

In conclusion, the current study enables the evaluation of the prevalence of HDV exposure among subjects surviving $\mathrm{HBV}$ infection in an endemic area. A prevalence of 9.6\% anti-HDV was found among subjects who had previous $\mathrm{HBV}$ infection. The clinical course of HDV infection is variable. Though HBV/HDV coinfection is the most severe form of viral hepatitis, milder forms of the dual infection or the resolution of both infections have been identified. Additional HDV testing for the detection of previous HDV exposure is required in endemic areas and in those taking immunosuppressive medications, particularly corticosteroids.

Conflict of Interest: On behalf of all authors, the corresponding author states that there is no conflict of interest.

Financial Disclosure: The authors declared that this study has received no financial support.

Authorship contributions: Concept - A.S., M.Y.; Design - A.S., Z.A.T.; Supervision - H.A., I.H.B.; Materials - S.G., N.T.; Data collection \&/or processing - A.S., U.D., O.K.P.; Analysis and/or interpretation - H.A., Z.A.T.; Writing - A.S.; Critical review - H.A., M.Y.

\section{REFERENCES}

1. Alvarado-Mora MV, Locarnini S, Rizzetto M, Pinho JR. An update on HDV: virology, pathogenesis and treatment. Antivir Ther 2013;18:541-8. [CrossRef] 
2. Sureau C, Negro F. The hepatitis delta virus: Replication and pathogenesis. J Hepatol 2016;64:S102-16. [CrossRef]

3. Rizzetto M. Current management of delta hepatitis. Liver Int 2013;33 Suppl 1:195-7. [CrossRef]

4. Noureddin M, Gish R. Hepatitis delta: epidemiology, diagnosis and management 36 years after discovery. Curr Gastroenterol Rep 2014;16:365. [CrossRef]

5. Türkdoğan MK, Bozkurt H, Uygan I, Tuncer I, Irmak H, Buzgan T, et al. Chronic hepatitis delta virus infection in Van region of eastern Turkey. Turk J Gastroenterol 2005;16:17-20.

6. Bahcecioglu IH, Aygun C, Gozel N, Poyrazoglu OK, Bulut Y, Yalniz M. Prevalence of hepatitis delta virus (HDV) infection in chronic hepatitis B patients in eastern Turkey: still a serious problem to consider. J Viral Hepat 2011;18:518-24. [CrossRef]

7. Değertekin H, Yalçin K, Yakut M, Yurdaydin C. Seropositivity for delta hepatitis in patients with chronic hepatitis B and liver cirrhosis in Turkey: a meta-analysis. Liver Int 2008;28:494-8. [CrossRef]

8. Kose S, Ece G, Gozaydin A, Turken M. Study on seroprevalence of hepatitis delta in a regional hospital in western Turkey. J Infect Dev Ctries 2012;6:782-5. [CrossRef]

9. Reinheimer C, Doerr HW, Berger A. Hepatitis delta: on soft paws across Germany. Infection 2012;40:621-5. [CrossRef]

10. Stroffolini T, Sagnelli E, Sagnelli C, Russello M, De Luca M, Rosina F, et al; behalf of EPACRON study group. Hepatitis delta infection in Italian patients: towards the end of the story? Infection 2017;45:277-81.

11. Celen MK, Ayaz C, Hosoglu S, Geyik MF, Ulug M. Anti-hepatitis delta virus seroprevalence and risk factors in patients with hepatitis $B$ in Southeast Turkey. Saudi Med J 2006;27:617-20.

12. Liaw YF, Sheen IS, Chen TJ, Chu CM, Pao CC. Incidence, determinants and significance of delayed clearance of serum HBsAg in chronic hepatitis B virus infection: a prospective study. Hepatology 1991;13:627-31. [CrossRef]

13. Fattovich G, Bortolotti F, Donato F. Natural history of chronic hepatitis B: special emphasis on disease progression and prognostic factors. J Hepatol 2008;48:335-52. [CrossRef]

14. Yuan T, Jiang Y, Li M, Li W. Chronic hepatitis B surface antigen seroclearance-related immune factors. Hepatol Res 2017;47:49-59.

15. Simonetti J, Bulkow L, McMahon BJ, Homan C, Snowball M, Negus S, et al. Clearance of hepatitis B surface antigen and risk of hepatocellular carcinoma in a cohort chronically infected with hepatitis B virus. Hepatology 2010;51:1531-7. [CrossRef]

16. Terrault NA, Bzowej NH, Chang KM, Hwang JP, Jonas MM, Murad MH; American Association for the Study of Liver Diseases. AASLD guidelines for treatment of chronic hepatitis B. Hepatology 2016;63:261-83. [CrossRef]

17. European Association for the Study of the Liver. EASL 2017 Clinical Practice Guidelines on the management of hepatitis B virus infection. J Hepatol 2017;67:370-98. [CrossRef]

18. Weller IV, Karayiannis P, Lok AS, Montano L, Bamber M, Thomas $\mathrm{HC}$, et al. Significance of delta agent infection in chronic hepatitis B virus infection: a study in British carriers. Gut 1983;24:1061-3.

19. Novick DM, Farci P, Karayiannis P, Gelb AM, Stenger RJ, Kreek MJ, Thomas HC. Hepatitis D virus antibody in $\mathrm{HBsAg}$-positive and $\mathrm{HBs} A g$-negative substance abusers with chronic liver disease. J Med
Virol 1985;15:351-6. [CrossRef]

20. Inoue J, Takahashi M, Nishizawa T, Narantuya L, Sakuma M, Kagawa $Y$, et al. High prevalence of hepatitis delta virus infection detectable by enzyme immunoassay among apparently healthy individuals in Mongolia. J Med Virol 2005;76:333-40. [CrossRef]

21. Genné D, Rossi I. Hepatitis delta in Switzerland: a silent epidemic. Swiss Med Wkly 2011;141:w13176. [CrossRef]

22. Niro GA, Gravinese E, Martini E, Garrubba M, Facciorusso D, Conoscitore $\mathrm{P}$, et al. Clearance of hepatitis B surface antigen in chronic carriers of hepatitis delta antibodies. Liver 2001;21:254-9. [CrossRef]

23. Romeo R, Del Ninno E, Rumi M, Russo A, Sangiovanni A, de Franchis $\mathrm{R}$, et al. A 28-year study of the course of hepatitis Delta infection: a risk factor for cirrhosis and hepatocellular carcinoma. Gastroenterology 2009;136:1629-38. [CrossRef]

24. Buti M, Homs M, Rodriguez-Frias F, Funalleras G, Jardí R, Sauleda S, et al. Clinical outcome of acute and chronic hepatitis delta over time: a long-term follow-up study. J Viral Hepat 2011;18:434-42. [CrossRef]

25. Pondé RAA. The serological markers of acute infection with hepatitis A, B, C, D, E and G viruses revisited. Arch Virol 2017;162:3587-602.

26. Pascarella S, Negro F. Hepatitis D virus: an update. Liver Int 2011;31:7-21. [CrossRef]

27. Mederacke I, Filmann N, Yurdaydin C, Bremer B, Puls F, Zacher BJ, et al. Rapid early HDV RNA decline in the peripheral blood but prolonged intrahepatic hepatitis delta antigen persistence after liver transplantation. J Hepatol 2012;56:115-22. [CrossRef]

28. Olivero A, Smedile A. Hepatitis delta virus diagnosis. Semin Liver Dis 2012;32:220-7. [CrossRef]

29. Chow SK, Atienza EE, Cook L, Prince H, Slev P, Lapé-Nixon M, et al. Comparison of Enzyme Immunoassays for Detection of Antibodies to Hepatitis D Virus in Serum. Clin Vaccine Immunol 2016;23:732-4.

30. Chen X, Oidovsambuu O, Liu P, Grosely R, Elazar M, Winn VD, et al. A novel quantitative microarray antibody capture assay identifies an extremely high hepatitis delta virus prevalence among hepatitis B virusinfected mongolians. Hepatology 2017;66:1739-49. [CrossRef]

31. Fouad R, Abdo M, Eldeen HG, Sabry D, Atef M, Ahmed R, et al. Influence of delta virus infection on the virologic status in Egyptian patients with chronic hepatitis B virus genotype D. J Med Virol 2016;88:83742. [CrossRef]

32. Delfino CM, Eirin ME, Berini C, Malan R, Gentile E, Castillo A, et al. HDAg-L variants in covert hepatitis D and HBV occult infection among Amerindians of Argentina: new insights. J Clin Virol 2012;54:223-8. [CrossRef]

33. Smedile A, Rizzetto M. Orthotopic liver transplantation for chronic viral hepatitis: an overview. Int J Clin Lab Res 1992;22:211-5. [CrossRef]

34. Ottobrelli A, Marzano A, Smedile A, Recchia S, Salizzoni M, Cornu $C$, et al. Patterns of hepatitis delta virus reinfection and disease in liver transplantation. Gastroenterology 1991;101:1649-55. [CrossRef]

35. Smedile A, Casey JL, Cote PJ, Durazzo M, Lavezzo B, Purcell RH, et al. Hepatitis D viremia following orthotopic liver transplantation involves a typical HDV virion with a hepatitis B surface antigen envelope. Hepatology 1998;27:1723-9. [CrossRef]

36. Miyaaki H, Tamada Y, Hayashi K, Taura N, Miuma S, Shibata H, et al. Recurrent Hepatitis B and D Virus Infection in a Liver Transplant Recipient. Transplant Proc 2017;49:175-7. [CrossRef] 